\title{
Comparative Evaluation of the Effects of Soil and Fertilizer Treatment on Winter Wheat Cultivation
}

\author{
RAE ZH Aliyev* \\ Institute of Erosion and Irrigation NAS of Azerbaijan, Azerbaijan
}

Received: December 20, 2017; Published: January 18, 2018

*Corresponding author: RAE ZH Aliyev, Institute of Erosion and Irrigation NAS of Azerbaijan, Azerbaijan

\section{Abstract}

The article gives the results of studies of the effect of soil and fertilizer treatment on the productivity of winter wheat in the Ganja-Gazakh zone of Azerbaijan (Figure 1). The positive effect of fertilizers on plants of winter wheat is manifested only in well-cultivated soils with a reaction of the environment close to neutral. At the same time it is proved that between the intensity of the application of mineral fertilizers and the productivity of grain crops around the world, a close direct dependence is established. Consequently, the highest yield of grain here was obtained in the variant of dung $10 \mathrm{t} / \mathrm{ha}+\mathrm{N} 90 \mathrm{P} 90 \mathrm{~K} 6057.1 \mathrm{c} / \mathrm{ha}$, an increase of $24.3 \mathrm{c} /$ ha or $74.1 \%$, where the yield increase by $40-50 \%$ is due to the application of fertilizers

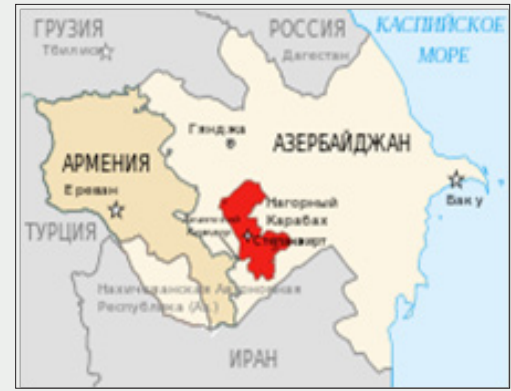

Figure 1.

Keywords: Winter wheat, Soil treatment, Traditional, Minimal, Manure, Mineral fertilizers, Yield

\section{Introduction}

World science and practice at the present stage of development in the field of agriculture convincingly prove the possibilities of developing energy and resource-saving technologies for cultivating agricultural crops. The main directions of development envisage the production of competitive products subject to the introduction of minimization of soil cultivation on the basis of optimization of the structure of sown areas and crop rotations, the fertilizer system, protection of soil fertility and other parts of farming systems, taking into account the soil-climatic features of the territory [1]. Resourcesaving technologies in soil cultivation are one of the most promising methods of land use, developed in our time. In this experiment, winter wheat was studied, the yield of which was directly related to the cultivation of soil and the application of organic and mineral fertilizers. In the complex of agro technical measures that contribute to obtaining high yields of food grain of winter wheat, fertilizers have a leading role. We, skillfully using fertilizers, tried to improve the quality of grain, increasing its protein content, gluten content and technological properties.

\section{The Purpose and Objectives of the Study}

The purpose of our research is to study the methods of soil and fertilizer cultivation, improve soil fertility and winter wheat cultivation technology, which ensures higher yield and quality of grain in the Ganja-Gazakh zone of Azerbaijan.

\section{The Course of the Study}

On the basis of the conducted studies it was established that in order to obtain a high and high-quality harvest of winter wheat grain and restore soil fertility on gray-brown long-irrigated soils of this zone, it is recommended that farms (traditional loosening 20-22 cm) and minimal tillage, using fertilizers annually in norm of manure is $10 \mathrm{t} /$ ha $+\mathrm{N} 90 \mathrm{P} 90 \mathrm{~K} 60$. As a result, both cultivation 
of soil treatments and the rate of fertilizers are recommended, in addition, after 3 years the minimum treatment should be replaced by a traditional one. Winter wheat is one of the main food crops in Azerbaijan. In 2015, the total area of winter and spring wheat sowing in the Republic was 539679 hectares, the total grain production was 1687681 tons, the average yield was 31.3 center / ha. In the Ganja-Gazakh zone, 48887 hectares, 154236 tons and 31.6 center / ha, respectively, and the place of the Samukh region's experience, respectively, 4784 hectares, 15773 tons and 33.0 center / ha [10]. Winter wheat is one of the most important, the most valuable and high-yield cereal crops. Its value is that the grain is high in protein and carbohydrates, along with spring wheat it is widely used in bakery, macaroni, and confectionery industry [2]. When cultivating agricultural crops, basic, presowing and postsowing soil cultivation is carried out. They account for about $40 \%$ of energy and $25 \%$ of labor costs [3].

Scientifically grounded soil cultivation provides accumulation and preservation of moisture in the root zone, mobilization of nutrients, and effective control of weeds, diseases, pests, and creation of optimal agro physical conditions for biological processes in the arable layer, growth and development of cultivated plants. The soil cultivation system in agriculture should be aimed at maximizing the use of local bioclimatic resources, biological and agro-technical methods for regulating the productivity of arable land [4]. Plant nutrition is the most important factor in the productivity of crops. Between the intensity of the application of mineral fertilizers and the productivity of grain crops around the world, a close direct relationship has been established. The increase in yields by $40-50 \%$ is due to the use of fertilizers. At the present stage of the development of agriculture, the main direction in improving the mechanical treatment of the soil is its minimization - a reduction in intensity due to a reduction in the number and depth of processing, and the combination of a number of technological operations in one pass of the aggregate along the field by using combined machines and tools. In modern agricultural production, the issues of developing new low-cost technologies for crop cultivation, effective removal of the causes of soil degradation, as well as negative consequences of man-made impact on soil, are more acute than ever. One of the topical issues in the technology of growing grain crops is resource conservation. It is well known that in traditional technologies, $50 \%$ of the cost falls on the basic tillage in the form of plowing to a depth of $20-22 \mathrm{~cm}$. At the same time, there is very limited material on the effectiveness of the surface and small-scale uncontaminated soil cultivation and very little data on the results of the systematic application of zero processing to all crops of crop rotation [5-8].

\section{Methodology of Research}

-The studies were conducted in 2012-2015 in the Central Experimental Base of the Azerbaijan Research Institute of Cotton Growing located in the western zone of Azerbaijan. The scheme of the experiment is two-factor $(2 \times 4)$ with the following factors.

Factor a: Soil processing:
a) Traditional processing (loosening $20-22 \mathrm{~cm}$ )
b) Minimal processing (10-12 $\mathrm{cm}$ of chisel).

Factor b: Doses of fertilizers:

a) Without fertilizer

b) Manure 10t / ha + N60P60K30

c) Manure 10t / ha + N90P90K60

d) The manure is $10 \mathrm{t} / \mathrm{ha}+\mathrm{N} 120 \mathrm{P} 120 \mathrm{~K} 90$.

The precursor of winter wheat was cotton. The soil of the experimental site is carbonate, long irrigated, gray-brown, and easily loamy. The content of nutrients decreases from top to bottom in the meter horizon. According to the accepted gradation in the country, agrochemical analysis shows that these soils are poorly provided with nutrients and require the use of organic and mineral fertilizers. The content of total humus (according to Tyurin) in the $0-30$ layer and $60-100 \mathrm{~cm}, 2.15-0.85 \%$, gross nitrogen and phosphorus (according to KE Ginzburg) and potassium (according to Smith), respectively, is $0.15-0.06 \% ; 0,13-0,07 \%$ and $2,39-1,51 \%$, absorbed ammonia (according to Konev) 18,0-6,5 mg / kg, nitrate nitrogen (according to Grandval-Liazhu) 9,7-2,6 mg / kg, mobile phosphorus (according to Machigin) 15.8-4.5 mg / kg, exchange potassium (according to Protasov) 263.5-105.3 mg / kg, pH of the aqueous suspension is 7.8-8.4 (in potentiometer). And also the physico-chemical composition of the soils of the experimental site was studied. Experimental fields are characterized by a high sum of exchange bases, reaching in the plowing layer $29.8 \mathrm{meq} / 100 \mathrm{~g}$ soil. With depth, it decreases; reaching a minimum in the layer of 60 $100 \mathrm{~cm}$ is $21.1 \mathrm{meq} / 100 \mathrm{~g}$ of soil. Soil density is $1.19-1.31 \mathrm{~g} / \mathrm{cm} 3$, respectively. Agrotechnics of growing of winter wheat of "Gobustan" variety is traditional for the zone. The total plot area is $56 \mathrm{~m} 2$, accounting $50.4 \mathrm{~m} 2$, the repetition is three-fold, and the location of the plots is randomized. Annually manure, phosphorus and potassium were brought in autumn for plowing, nitrogen fertilizers were used in spring 2 times as a fertilizer. Experience was laid down by methodical instructions (M.: VIUA, 1975) by the method of comb-seeding at the rate of $200 \mathrm{~kg} / \mathrm{ha}$. As mineral fertilizers, nitrogen-ammonium nitrate, phosphorus-simple superphosphate, potassium-sulfate potassium are used here [9].

\section{Results and Discussion}

In the traditional treatment of soils, on average, over the years of research, the collection of winter wheat grain in a fertilizer-free version amounted to $32.8 \mathrm{c} /$ ha (Fig. 1). In the variant, the manure $10 \mathrm{t} / \mathrm{ha}+\mathrm{N} 60 \mathrm{P} 60 \mathrm{~K} 30$ the grain yield is $40.1 \mathrm{c} / \mathrm{ha}$, the increment is $7.3 \mathrm{c} /$ ha or $22.3 \%$. The highest yield of grain was obtained in the variant of manure 10t / ha + N90P90K60 $57.1 \mathrm{c} / \mathrm{ha}$, an increase of $24.3 \mathrm{c} /$ ha or $74.1 \%$. With a further increase in the doses of mineral fertilizers on the background of manure (N120P120K90), the grain collection increased insignificantly $50.0 \mathrm{c} / \mathrm{ha}$, the increment was $17.2 \mathrm{c} /$ ha $(52.4 \%)$ of grain. Mathematical processing of the obtained data showed their reliability: $\mathrm{P}=1.38-2.47 \%$; $\mathrm{E}=0.58$ 1.16 center / ha 


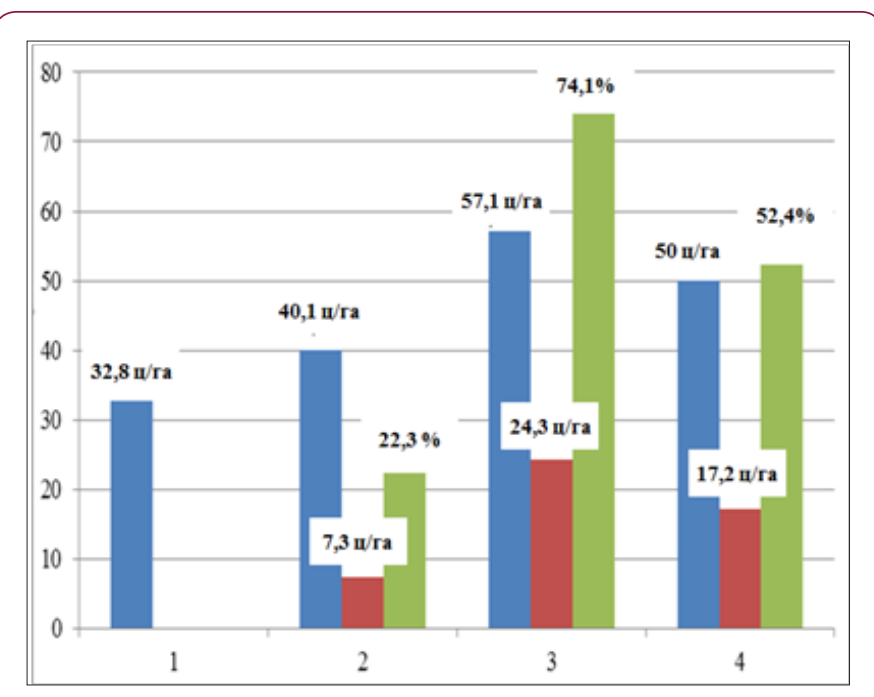

Figure 2: The influence of traditional processing and fertilizer rates on the yield of winter wheat (for 3 years).

$\mathrm{E}=0.58-1.16 \mathrm{c} / \mathrm{ha}$

$\mathrm{P}=1.38-2.47 \%$

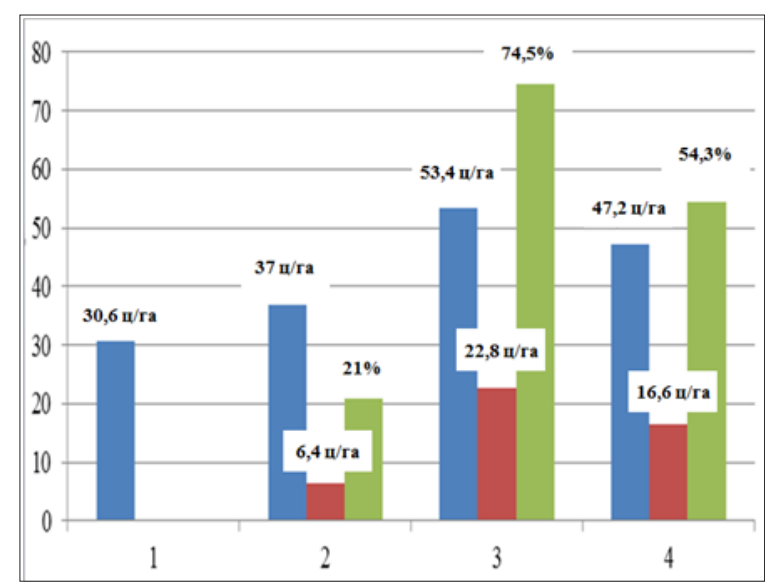

Figure 3: The effect of minimum processing and fertilizer rates on the yield of winter wheat (for 3 years).

Figure 2 the influence of traditional processing and fertilizer rates on the yield of winter wheat (for 3 years) with minimal soil treatment, on average, for the years of research, the collection of winter wheat grain in an unsophisticated version amounted to 30.6 c / ha (Figure 3). In the variant, manure $10 \mathrm{t} /$ ha + N60P60K30 grain yield $37.0 \mathrm{c} / \mathrm{ha}$, an increase of $6.4 \mathrm{c} / \mathrm{ha}$ or $21.0 \%$. The highest grain yield was obtained in the variant of dung $10 \mathrm{t} / \mathrm{ha}$
+ N90P90K60 $53.4 \mathrm{c} / \mathrm{ha}$, an increase of $22.8 \mathrm{c} /$ ha or $74.5 \%$. With a further increase in the doses of mineral fertilizers on the background of manure (N120P120K90), the grain collection increased insignificantly $47.2 \mathrm{c} / \mathrm{ha}$, the increment was $16.6 \mathrm{c} / \mathrm{ha}$ $(54.3 \%)$ of grain.

Mathematical processing of the obtained data showed their reliability: $\mathrm{P}=1,83-2,50 \%$; $\mathrm{E}=0.75-1.06 \mathrm{t} /$ ha.

\section{Conclusion}

Thus, on the basis of the studies carried out, it can be concluded that in order to obtain a high and qualitative harvest of winter wheat grain and restore fertility of soils on gray-brown, long-irrigated soils to this zone, it is recommended that traditional farms (loosening 20-22 cm) and minimal tillage, also the use of fertilizers annually in the norm of manure is $10 \mathrm{t} / \mathrm{ha}+\mathrm{N} 90 \mathrm{P} 90 \mathrm{~K} 60 \mathrm{~kg} / \mathrm{ha}$. As a result, both cultivation of soil treatments and the rate of fertilizers are recommended, in addition, after 3 years the minimum treatment should be replaced by a traditional one.

\section{References}

1. Garkusha AA (2002) Efficiency of methods of minimizing presowing tillage and care for spring wheat crops in the conditions of the Altai $\mathrm{Ob}$ area. Dis ks x sciences Barnaul 134.

2. Craft VN, Saiko VF (1978) Shevchenko AI Harvest and quality of wheat depending on the variety the norm of sowing doses of fertilizers. Bulletin of Agricultural Sciences (10): 63-69.

3. Bakirov FG, Petrova GV, Dolmatov AP, Petrov DG (2014) Resource saving technologies on chernozems of the Orenburg region. Achievements of science and technology of agroindustrial complex (5): 3-5.

4. Ilyasov MM, Yapparov AKH, Shaikhutdinov FSH (2014) The formation of the winter wheat crop depending on the fertilizer system while minimizing the main soil cultivation. Bulletin of the Kazan GAU 1(31): $65-75$.

5. Kazantsev SI (2013) Efficiency of minimal methods of basic soil cultivation in a link of grain growing crop rotation on typical chernozems of Central Chernozem. Dis ccx nauk Eagle 150.

6. Drobyshev AP Optimization of crop rotations and basic tillage in resource saving agriculture in the south of Western Siberia. Diss ps $x$ sciences Moscow (213): 320.

7. Semizorov SA (2013) Differentiated basic processing of meadow chernozem soil at different levels of mineral nutrition in the Northern Trans Urals. Dis cs x sciences Krasnoyarsk 206.

8. Shabaev AI, Kholinsky NM, Azizov NM, Sokolov NM (2007) Resource saving soil protection treatment of soil in agro landscapes of the Volga region. Zemledelia (1): 20-22.

9. Yagodin BA, Zhukov YuP, Kobzarenko VI (2004) Agro chemistry Ed BA Yagodin Moscow Mir 584. 
(c) This work is licensed under Creative

DOI: 10.32474/CIACR.2018.01.000101

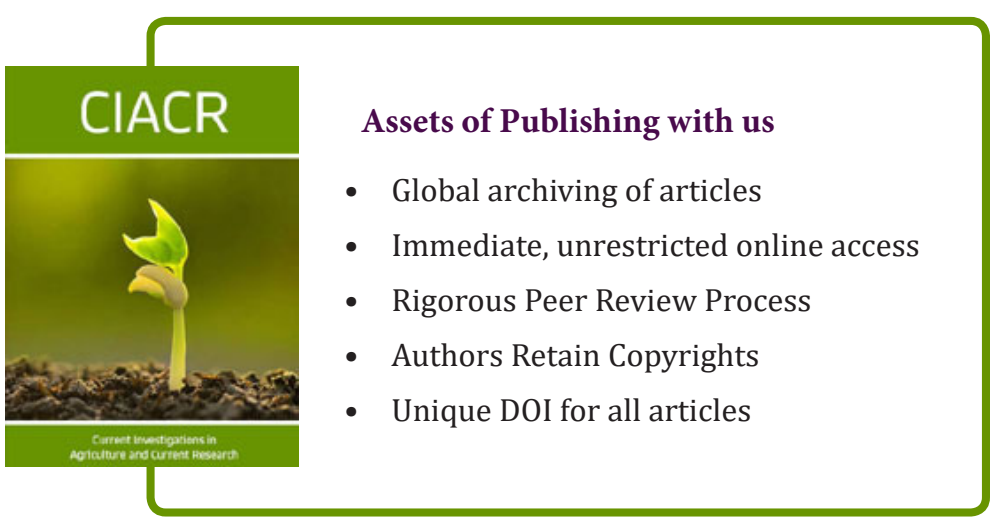

